\title{
Artikel
}

\section{Snelrecht: voor elk wat wils, maar wat willen} we?

\author{
De (on)mogelijkheden van snelrecht in het kader van 'lik-op-stuk' en efficiency
}

Mr. dr. J.M.W. (Joep) Lindeman, mr. dr. L. (Leonie) van Lent en mr. dr. B. (Benny) van der Vorm*

\section{Inleiding}

Het snelrecht is al geruime tijd een van de afdoeningsmodaliteiten in de strafrechtketen. Achter de ogenschijnlijk eenvoudige term gaat een lastig te beschrijven werkelijkheid schuil, die bovendien niet in alle arrondissementen hetzelfde is. De term wordt vaak generiek gebruikt voor alles wat met snelle afdoening te maken heeft, maar in de praktijk en het beleid wordt op zijn minst een onderscheid gemaakt tussen 'supersnelrecht' en 'snelrecht', allebei vormen van berechting, ${ }^{1}$ terwijl de 'ZSM-werkwijze' een (inmiddels standaard) ketenbrede aanpak is die kan uitmonden in alle afdoeningsvormen, zeker ook buitengerechtelijke.

Het 'snelrecht' is in de coronacrisis nadrukkelijker op de kaart gezet, en wel met verschillende doelen en achtergronden. Aan het begin van de crisis was er veel aandacht voor de 'coronaspugers'. Hoewel de rechtbanken goeddeels gesloten waren, zette het OM erop in om

* Joep Lindeman is universitair hoofddocent straf- en strafprocesrecht Leonie van Lent is universitair docent straf- en strafprocesrecht en Benny van der Vorm is universitair docent straf- en strafprocesrecht. Allen zijn werkzaam bij het Willem Pompe Instituut voor strafrechtswetenschappen van de Universiteit Utrecht en verbonden aan het Montaigne Centrum voor Rechtsstaat en Rechtspleging van dezelfde universiteit.

1. In de praktijk van de verschillende rechtbanken heeft de vorm die wij hier 'snelrecht' noemen, ook wel de benaming Politierechter Gedetineerden (PRG). In het strafprocesreglement wordt dit 'Snelrecht Gedetineerden' (SRG) genoemd. In dat reglement wordt ook de variant 'Snelrecht Niet Gedetineerden' (SRNG) genoemd. deze verdachten via (super)snelrecht te laten berechten en eiste hoge straffen - die inderdaad werden opgelegd. Enige tijd later gebeurde hetzelfde met de avondklokrellers.

Tegelijk met de avondklokrellen werd in de Tweede Kamer gedebatteerd over de uitbreiding van het taakstrafverbod: een wetswijziging die, zoals we hieronder zullen toelichten, de nodige impact zou kunnen hebben op de praktijk van het snelrecht. Ook wordt het snelrecht door het Bestuurlijk Ketenberaad ${ }^{2}$ nadrukkelijk genoemd als een van de oplossingen om de door de coronacrisis veroorzaakte achterstanden in de strafrechtketen in te lopen. ${ }^{3}$

Deze verschillende manieren om snelrecht in te zetten zijn illustratief voor de brede waaier aan opvattingen en associaties rondom dit fenomeen, die al ruimschoots voor het begin van de coronacrisis hun intrede deden. In de Tweede Kamer doemt het snelrecht regelmatig op als een middel om te komen tot een 'lik-op-stuk' aanpak van (bepaalde) strafbare feiten en hun plegers, terwijl

2. Het Bestuurlijk Ketenberaad (BKB) is het politiek-bestuurlijke beraad waar ketenorganisaties en het ministerie van Justitie en Veiligheid afspraken maken over de samenwerking en de prestaties van de strafrechtketen. Het BKB bestaat uit een onafhankelijk voorzitter, de voorzitter van het College van procureurs-generaal, de voorzitter van de Raad voor de rechtspraak, de korpschef van de politie, de algemeen directeur CJIB (namens de executiepartners) en de directeur-generaal rechtspleging en rechtshandhaving (namens de ministers en het ambtelijk apparaat JenV), de directeur Wetgeving en Juridische Zaken en de directeur Strafrechtketen; zie www.strafrechtketen.nl/onderwerpen/bestuurlijkketenberaad.

3. 'Actieplan strafrechtketen', Bestuurlijk Ketenberaad, 6 november 2020, bijlage (blg-956897) bij Kamerstukken II 2020/21, 29279, nr. 628; 'Position paper: een duurzame en toekomstbestendige strafrechtketen', bijlage (blg-976190) bij Kamerstukken /l 2020/21, 29 279, nr. 644. 
binnen de strafrechtketen daarnaast (of: bovenal) kansen worden gezien voor een (zeer) efficiënte werkwijze. Van een weldoordacht beleid op het terrein van het snelrecht lijkt echter nauwelijks sprake te zijn. Dat is niet onproblematisch, nu de wens om snel te berechten op gespannen voet staat met verschillende procedurele waarborgen omtrent het strafproces, zoals de onschuldpresumptie en het recht op adequate verdedigingsfaciliteiten. Aangezien een kenmerkend aspect van berechting via het snelrecht is dat de verdachte in de aanloop naar zijn proces in voorarrest zit, komt de toepassing van snelrecht bovendien in het vaarwater van artikel 5 EVRM.

Alle reden dus om het snelrecht onder de loep te nemen. In deze bijdrage zetten wij op een rij welke vormen van snelrecht er in de praktijk zijn, hoe de inzet ervan wordt gereguleerd en welke doelstellingen en opvattingen daarbij een rol spelen (par. 2). Vervolgens bespreken wij aan de hand van een aantal recente ontwikkelingen de 'contexten' waarin (in wet, beleid en praktijk) het snelrecht een rol krijgt toegedacht (par. 3). Aan het eind van deze bijdrage beargumenteren wij in welke situaties en onder welke voorwaarden er binnen de strafrechtspleging (g)een plaats is voor snelrecht (par. 4). ${ }^{4}$

\section{Snelrecht}

\subsection{Vormen en 'normen' van snelrecht}

Het enige met goede wil als rechtsbron te betitelen document dat duiding geeft aan de begrippen 'snelrecht' en 'supersnelrecht' is de door het College van procureurs-generaal (hierna: College van PG's) ontwikkelde Menukaart (super) snelrecht uit oktober 2009. ${ }^{5}$ Sindsdien is (net als bijvoorbeeld op het terrein van de ZSM-werkwijze) door het OM nooit een voor de buitenwacht duidelijk beleidsdocument vervaardigd op basis waarvan duidelijk zou kunnen worden hoe de (super)snelrechtprocedure is ingericht en met welke waarborgen zij is omgeven. Ook het landelijk strafprocesreglement ${ }^{6}$ van de Rechtspraak bevat hieromtrent geen concrete instructies. ${ }^{7}$ Een Aanwijzing van het College van PG's

4. In deze bespreking baseren wij ons voor een belangrijk deel op ons onderzoek in het kader van de evaluatie van de Wet uitbreiding gronden voorlopige hechtenis (hierna: WUGVH), dat wij vorig jaar in opdracht van het WODC hebben uitgevoerd. Met die wet werd de zogenoemde 'snelrechtgrond' aan art. 67a lid 2 Sv toegevoegd, met als doel om 'bij geweld in de publieke ruimte en geweld tegen personen met een publieke taak de mogelijkheden voor de toepassing van voorlopige hechtenis te verruimen met het oog op een snelle berechting van de verdachte' (Kamerstukken /I 2011/12, 33 360, nr. 3, p. 1). Zie: J.M.W. Lindeman, L. van Lent, B. van der Vorm \& I.C. Smits, Wie past de schoen? Snelrechtgrond in de praktijk. Evaluatie van de Wet uitbreiding gronden voorlopige hechtenis (WODC-rapport 3019), Utrecht/Den Haag: Montaigne Centrum/WODC 2020

5. Bijlage bij Kamerstukken // 2009/10, 32 123-VI, nr. 84.

6. www.rechtspraak.nl/Voor-advocaten-en-juristen/Reglementenprocedures-en-formulieren/Strafrecht/Paginas/

Strafprocesreglement.aspx.

7. Er wordt slechts melding gemaakt, in 2.1.1, dat het OM bij de forumkeuze bij een enkelvoudige rechter kan kiezen uit verschillende varian- in de zin van artikel 130 lid 6 Wet RO had hier onzes inziens niet misstaan. De menukaart bevat namelijk een reeks dwingende, normatieve instructies met betrekking tot de toepassing van (super)snelrecht. ${ }^{8}$ Van 'supersnelrecht' is sprake 'indien de zaak binnen de termijn inverzekeringstelling (3 dagen) inhoudelijk wordt behandeld, voorlopige hechtenis wordt bevolen en een opgelegde vrijheidsstraf aansluitend wordt uitgezeten'. Met andere woorden: in plaats van een voorgeleiding aan de RC wordt de verdachte voorgeleid aan een als politierechter fungerende $\mathrm{RC}$, die onmiddellijk vonnis wijst ${ }^{9}$ en in aansluiting daarop de voorlopige hechtenis (bevel gevangenneming) van de veroordeelde kan bevelen. ${ }^{10}$ Van 'snelrecht' is sprake als de verdachte in bewaring is gesteld en de strafzaak binnen de termijn van die bewaring (14 dagen) door de politierechter wordt behandeld. De politierechter kan eventueel een bevel gevangenhouding geven ${ }^{11}$ in het geval de opgelegde vrijheidsstraf langer is dan de tot de zitting in voorlopige hechtenis doorgebrachte tijd (de vrijheidsbeneming). ${ }^{12}$ De menukaart stelt verder dat alleen relatief klip-en-klare zaken in aanmerking komen voor snelrecht. Het zou bijvoorbeeld moeten gaan om zaken waarin geen deskundigenrapport of voorlichtingsrapportage over de verdachte hoeft te worden opgemaakt en waarin een eventuele vordering van de benadeelde partij gemakkelijk is te behandelen.

De menukaart maakt dus nadrukkelijk duidelijk dat supersnelrecht en snelrecht gepaard gaan met de toepassing van voorarrest. Meer impliciet volgt eruit dat het niet de bedoeling is dat op basis van rapportages wordt

ten: de Politierechter, Supersnelrecht, Snelrecht Gedetineerden (SRG) en Snelrecht Niet Gedetineerden (SRNG).

8. Een aanwijzing in de zin van art. 130 lid 6 Wet RO is 'een publiekrechtelijke rechtshandeling van algemene aard met dwingende, normatieve beleidsregels, afkomstig van het College van procureurs-generaal, die wordt gericht tot de hoofden van de parketten', zie verder: J.M.W. Lindeman, Officieren van justitie in de 21e eeuw. Een verslag van participerend observatieonderzoek naar de taakopvatting en taakinvulling van officieren van justitie (diss. Utrecht), Den Haag: Boom juridisch 2017, para. 4.4 e.v.

9. Uiteraard kan dat alleen als de verdachte afstand heeft gedaan van de in art. 370 Sv bepaalde dagvaardingstermijn.

10. $E r$ is in geval van supersnelrecht geen sprake van een bevel gevangenneming of gevangenhouding dat binnen de krachtens art. 66 lid 1 Sv bedoelde termijn is gegeven. Daardoor is van verlenging van rechtswege op grond van art. 66 lid 2 Sv geen sprake. Het voorarrest van de verdachte is immers op een bevel inverzekeringstelling gebaseerd. De politierechter moet dus op de zitting een bevel gevangenneming geven (art. 65 lid 2 Sv), dat op grond van art. 66 lid 2 zestig dagen geldig blijft.

11. De verlenging van rechtswege van art. 66 lid $2 \mathrm{~Sv}$ is ook op snelrechtzaken niet van toepassing, omdat het voorarrest van de verdachte dan nog op een bevel tot bewaring is gebaseerd (en dus nog niet op een bevel gevangenhouding/-neming).

12. Tenzij de verdachte direct afziet van het recht om in hoger beroep te gaan (art. $381 \mathrm{~Sv}$ ), staat art. 6:1:16 Sv in de weg aan de tenuitvoerlegging van een rechterlijke beslissing. De enige manier om de verdachte dan toch in detentie te laten blijven is een bevel gevangenneming (supersnelrecht) of gevangenhouding (snelrecht), waarbij dan dus wel de eisen van art. 67 en 67a Sv moeten worden nagelopen. In ons evaluatieonderzoek kwamen wij tot de conclusie dat de nieuwe snelrechtgrond dan niet meer van toepassing is, omdat er dan immers geen sprake meer is van de situatie dat de berechting binnen de genoemde termijn zal plaatsvinden (Lindeman e.a. 2020, p. 90-92). 
nagedacht over de schorsing van de voorlopige hechtenis. Ofschoon het (super)snelrecht dus stevig gekoppeld is aan de toepassing van voorarrest, wordt het sinds kort ook mogelijk geacht dat snelrecht wordt toegepast in het geval van een niet-gedetineerde verdachte. ${ }^{13}$

\subsection{Beleid, doelstellingen en aannames}

In de Menukaart Snelrecht noemt het College van PG's snelrecht onder bepaalde voorwaarden 'wenselijk'. Daarbij denkt het aan situaties waarin 'het strafbare feit en/of de persoon vraagt om een lik-op-stuk-reactie om aan verdachte en maatschappij duidelijk te maken dat het betreffende gedrag als onaanvaardbaar wordt beschouwd, terwijl het tevens in het belang van de samenleving is dat daders [sic] na aanhouding pas weer op vrije voeten komen na het uitzitten van hun straf.' Deze zin laat een aantal veronderstellingen zien, die niet zijn onderbouwd of toegelicht: kennelijk zijn er strafbare feiten en/of personen die om een lik-op-stuk-reactie vragen. Kennelijk is zo'n reactie nodig om aan de verdachte (!) en de maatschappij duidelijk te maken dat het betreffende gedrag als onaanvaardbaar wordt beschouwd. Kennelijk is de samenleving gediend met het onmiddellijk opsluiten van de dader (zelfs als deze nog als verdachte wordt aangemerkt) om deze pas weer vrij te laten als de straf is uitgezeten. De personen die voor snelrecht in aanmerking zouden komen, zijn blijkens de menukaart met name veelplegers. De soorten strafbare feiten waarop (super)snelrecht zou kunnen worden toegepast zijn bijvoorbeeld strafbare feiten tijdens evenementen, geweld tegen personen met een publieke functie of uitgaansgeweld. Wederom zijn de keuzes voor deze categorieën gefundeerd op niet onderbouwde aannames. Over ordeverstoringen rondom evenementen als voetbalwedstrijden zegt de menukaart bijvoorbeeld: 'Een bestraffend oordeel gevolgd door het ondergaan van de opgelegde straf zo snel mogelijk volgend op het delict dempt de gevoelens van verontwaardiging in de samenleving.' ${ }^{14}$ Over geweld tegen personen met een publieke functie wordt opgemerkt: 'Het belang van de samenleving brengt mee dat daders zo snel als mogelijk is na aanhouding worden berecht en na bestraffing deze straf aansluitend ondergaan.' ${ }^{15}$

Het in de menukaart aldus beleden geloof in de maatschappelijke betekenis van het lik-op-stukbeleid is in het decennium na de totstandkoming van de menukaart vooral van de zijde van de regering keer op keer herhaald, bijvoorbeeld als het ging om misdragingen tijdens oud en nieuw of rondom voetbalwedstrijden - en dan vooral misdragingen tegen personen met een publieke taak. ${ }^{16}$ Steeds opnieuw kwam daarin de aanname naar voren dat in gevallen als deze onmiddellijke vrijheidsbeneming, een snel proces en snelle tenuitvoer-

13. Vgl. het strafprocesreglement van 2019, waarin de variant 'SRNG' wordt genoemd. Zie ook Lindeman e.a. 2020, p. 34. Zie ook het 'Actieplan Strafrechtketen'.

14. Menukaart, p. 3.

15. Menukaart, p. 3.

16. Lindeman e.a. 2020, p. 36-37, p. 43-45, zie ook de MvT bij de WUGVH (Kamerstukken II 2011/12, 33 360, nr. 3). legging van de onvoorwaardelijke vrijheidsstraf de enige manier is om op maatschappelijke onrust en verontwaardiging te reageren.

Zoals hiervoor al gesteld is er niet veel beleid openbaar geworden met betrekking tot de organisatie en de toepassing van snelrecht. Ongetwijfeld zijn er binnen de arrondissementen tussen OM en Rechtspraak praktische afspraken gemaakt, al dan niet in samenspraak met de lokale balie, maar een landelijke visie op het snelrecht als zodanig is, na de genoemde menukaart, niet meer gegeven. Op een aantal terreinen werd wel duidelijk dat het snelrecht als een gegeven werd beschouwd, zoals in het programma Veilige Publieke Taak (VPT). In het kader van dit programma is jarenlang veelomvattend beleid gevoerd om gewelddadig en intimiderend gedrag tegen politieagenten, brandweerlieden, ambulancebroeders etc. in te dammen. In zogenoemde Eenduidige Landelijke Afspraken (ELA) zijn over dit onderwerp tussen het $\mathrm{OM}$ en de politie afspraken gemaakt. ${ }^{17}$ Belangrijke afspraken betreffen bijvoorbeeld een flinke verhoging van de strafeis wanneer bepaalde strafbare feiten jegens werknemers met een publieke taak zijn gepleegd. ${ }^{18}$ Ook is afgesproken dat de vervolging en berechting voortvarend zal worden aangepakt, waar mogelijk met (super)snelrecht en/of het vorderen van voorlopige hechtenis. ${ }^{19}$ Uiteindelijk bleek de praktijk weerbarstig en konden de afspraken vaak niet worden nagekomen, waarop het OM te kennen heeft gegeven dat het beter zou zijn om de afspraken over snelrecht en voorlopige hechtenis maar te schrappen. ${ }^{20}$ Een belangrijke constatering in dit verband is dat de toepasselijke OMrichtlijnen voor strafvordering ${ }^{21}$ alsmede de aanwijzingen met betrekking tot het vervolgingsbeleid ${ }^{22}$ lang niet altijd in de richting van onvoorwaardelijke vrijheidsstraffen wijzen, zelfs niet met inachtneming van de forse strafverhoging die voor VPT-zaken wordt voorgeschreven. Anders gezegd: waar aan de ene kant werd afgesproken aan te sturen op voorlopige hechtenis en snelrecht, werd aan de andere kant strafvorderingsbeleid geformuleerd dat niet strookte met die afspraken.

Wat verder opvalt met betrekking tot het beleid, is dat het nauwelijks ingaat op mogelijke alternatieven: kan de lik-op-stukgedachte niet ook op een andere wijze worden bereikt? Ook is er weinig aandacht voor negatieve neveneffecten: is het belang van de samenleving bijvoorbeeld nog steeds gediend met lik-op-stuk als de onmiddellijke vrijheidsbeneming leidt tot ingrijpende

17. Lindeman e.a. 2020, p. 36-37; J. Kuppens, R. Rijnink, J. van Esseveld \& $\mathrm{H}$. Ferwerda, Afspraak is afspraak? Evaluatie van de eenduidige landelijke afspraken rondom opsporing en vervolging van geweld tegen werknemers met een publieke taak, Bureau Beke 2020.

18. Vgl. ook Aanwijzing kader voor strafvordering meerderjarigen van 1 april 2019, onder 6, Stcrt. 2019, 14890.

19. Lindeman e.a. 2020, p. 36; Kuppens e.a. 2020, p. 130-131

20. Kuppens e.a., 2020, p. 61-62, p. 103, p. 115.

21. Bijvoorbeeld die voor brandstichting (Stcrt. 2015, 4414), bedreiging (Stcrt. 2019, 14881), mishandeling (Stcrt. 2019, 14883), poging tot zware mishandeling (Stcrt. 2019, 14886), zware mishandeling (Stcrt. 2019, 14887) en openlijke geweldpleging (Stcrt. 2019, 14876).

22. O.a. Aanwijzing kader voor strafvordering meerderjarigen (Stcrt. 2019, 14890). 
'detentieschade' (verlies van werk, opleiding)? Bovendien lijkt nergens te worden stilgestaan bij de noodzaak om een bij snelle berechting passend systeem van rechtsbijstand te organiseren en te financieren, een probleem dat ook ten aanzien van de ZSM-werkwijze tot op de dag van vandaag bestaat. ${ }^{23}$

\section{Het snelrecht in verschillende contexten}

\subsection{Inleiding}

Uit het voorgaande volgt dat het snelrecht betekenis heeft in verschillende contexten, die vaak een (sterk) politieke en beleidsmatige kleuring hebben. In het onderstaande bespreken wij een aantal recente ontwikkelingen met betrekking tot die contexten, die soms ook in onderlinge samenhang moeten worden gezien. De voorlopige hechtenis heeft een belangrijke functie in de strafrechtelijke politiek van 'lik-op-stuk' en wordt, in die context, dus ook gezien als een belangrijke pijler van het systeem van (super)snelrecht. In dat verband zijn de gronden voor voorlopige hechtenis uitgebreid met de zogenoemde snelrechtgrond, wat niet tot veel verandering lijkt te hebben geleid (par. 3.2). In het afgelopen jaar heeft gewelddadig verzet tegen de handhaving in het kader van de coronacrisis (geweld tegen boa's en politie, avondklokrellen) herhaaldelijk tot de roep om toepassing van snelrecht geleid (par. 3.3) terwijl ongeveer tegelijkertijd de voorgestelde uitbreiding van het taakstrafverbod in de Tweede Kamer werd behandeld. Door die - op zich toevallige - samenloop van omstandigheden ontstond meer dan ooit een breed draagvlak voor de wens om verdachten direct aan te houden, in voorarrest te nemen en vervolgens snel tot een onvoorwaardelijke gevangenisstraf te laten veroordelen. De combinatie van de uitbreiding van het taakstrafverbod met de nieuwe snelrechtgrond voor voorlopige hechtenis neemt in potentie een aantal geconstateerde strafvorderlijke en praktische drempels ten aanzien van de toepassing van het snelrecht weg (par. 3.4). De coronacisis heeft het snelrecht ook op de kaart gezet als middel om de achterstanden in de strafrechtketen weg te werken (par. 3.5). In deze contexten lijkt het snelrecht dus steeds een belangrijk instrument. Daarbij is natuurlijk een aantal rechtsstatelijke kanttekeningen te plaatsen, wat wij in deze paragraaf (en in par. 4) dan ook zullen doen.

\subsection{De totstandkoming en evaluatie van de} snelrechtgrond voor voorlopige hechtenis

Het was mede het gegeven dat zogenoemde first offenders niet snel in voorlopige hechtenis worden genomen en (dus) niet snel in de snelrechtmolen terecht zouden

23. Pas heel recent is er financiering georganiseerd voor een zgn. telefonisch consult in het kader van ZSM-afdoeningen voor niet gedetineerde verdachten: www.rvr.org/nieuws/2021/maart/gratis-standaard-consult -bij-een-om-strafbeschikking.html. komen dat in 2012 leidde tot het wetsvoorstel om de zogenoemde snelrechtgrond aan het Wetboek van Strafvordering toe te voegen. ${ }^{24}$ In gevallen van geweld op openbare plaatsen en/of geweld tegen personen met een publieke taak zou, indien deze gedragingen maatschappelijke onrust veroorzaken, voorlopige hechtenis mogelijk moeten zijn als er een snelrechtprocedure in het verschiet zou liggen. De Wet uitbreiding gronden voorlopige hechtenis (hierna: WUGVH) is in 2015 in werking getreden. ${ }^{25}$

De toegevoegde waarde van het voorstel en de werkbaarheid ervan zijn van meet af aan breed ter discussie gesteld, waarbij de volgende argumenten vooral een rol speelden: de bestaande gronden (en dan met name de grote recidivegrond, die zelfs ten aanzien van first offenders kan worden toegepast ${ }^{26}$ ) zouden al voldoende armslag bieden; veel van de beoogde misdrijven zouden zich vanwege de complexiteit niet lenen voor een snelrechtprocedure; men voorzag dat het anticipatiegebod in veel gevallen in de weg zou staan aan het toepassen van voorlopige hechtenis bij first offenders en het was bovendien onduidelijk wat nu precies onder 'maatschappelijke onrust' zou moeten worden verstaan. ${ }^{27}$ Zeker met betrekking tot het laatste blinkt de wetsgeschiedenis van de WUGVH niet uit in duidelijkheid, maar uiteindelijk lijkt het toch het uitgangspunt van de minister te zijn geweest dat elke situatie van geweld in de openbare ruimte of tegen een persoon met een publieke taak intrinsiek tot 'maatschappelijke onrust' leidt, dat het snel reageren op deze misdrijven tegemoetkomt aan deze gevoelens én dat maatschappelijke onrust bovendien aanwezig wordt verondersteld bij een als prematuur beleefde vrijlating van de verdachte. Deze aannames zouden - in ieder geval voor korte duur - een voldoende concrete onderbouwing van voorlopige hechtenis zijn, die volgens de minister in lijn is met de jurisprudentie van het EHRM.

Het evaluatieonderzoek naar de WUGVH wijst uit dat de kritiek bewaarheid is. De grond wordt nauwelijks gebruikt: zaken van openlijk geweld of mishandeling tegen personen met een publieke taak zijn bewijstechnisch vaak complex en kunnen daarom lastig snel worden afgedaan. Als slachtoffers zich als benadeelde partij willen voegen, is de termijn voor snelrecht daarvoor ook vaak te kort. In minder ernstige gevallen die wellicht gemakkelijker snel zijn af te doen, ligt bij

24. Kamerstukken I/ 2012/13, 33 360, nr. 1-3.

25. Stb. 2014, 176 en Stb. 2014, 316 (Iwtr.).

26. J.H. Janssen, F.W.H. van den Emster \& T.B. Trotman, 'Strafrechters over de praktijk van de voorlopige hechtenis', Strafblad 2013, p. 430-444; M.M. Boone, P. Jacobs \& J.M.W. Lindeman, 'Alternatieven voor voorlopige hechtenis in Europa en Nederland: de advocaat als onterechte sleutelhouder', DD 2019, p. 170-187.

27. Lindeman e.a. 2020 p. 43-67, waarin o.a. wordt verwezen naar de consultatieadviezen van de NOvA, de RvdR en de NVvR (bijlagen bij Kamerstukken // 2011/12, 33 360, nr. 3) en naar: M. Haveman \& L. van Lent, 'Vastzetten om het vastzitten. Evaluatie van het van het concept-wetsvoorstel tot wijziging van het Wetboek van Strafvordering in verband met de uitbreiding van de gronden voor voorlopige hechtenis', AA 2012, p. 94-101; Kwakman 2012; G.P.M.F. Mols, 'Uitbreiding gronden voorlopige hechtenis: meer is niet beter', NBSTRAF 2014/28. 
first offenders een onvoorwaardelijke vrijheidsstraf weer niet in de rede, zodat het anticipatiegebod in de weg staat aan het toepassen van voorlopige hechtenis en (dus) aan snelrecht. Recidivisten kunnen daarentegen 'gewoon' op de recidivegrond worden vastgehouden. De situatie die de wetgever voor ogen had, komt in de praktijk nauwelijks voor: er is vrijwel nooit sprake van een first offender die een relatief gemakkelijk te bewijzen strafbaar feit heeft gepleegd dat binnen de parameters van de snelrechtgrond valt, maar waarop geen andere gronden voor voorlopige hechtenis van toepassing zijn en waarvoor wel een onvoorwaardelijke vrijheidsstraf te verwachten is. Waar de minister nog enkele honderden gevallen per jaar verwachtte, ${ }^{28}$ kwamen wij - over een tijdspanne van 29 maanden! - op een ruwe schatting van 190 tot 270 gevallen, een fractie van het totale aantal gevallen van voorlopige hechtenis (ca. 14.000 per jaar). ${ }^{29}$ Het blijkt in de praktijk voor officieren van justitie en rechters lastig om handen en voeten te geven aan het criterium dat het gepleegde strafbare feit tot 'maatschappelijke onrust' heeft geleid. Wij noemen in ons rapport de (hierboven al weergegeven) uitleg van de minister van dit begrip 'caleidoscopisch' en benadrukken het gevaar van de maatschappelijke onrust als selffulfilling prophecy. Ons onderzoek wijst ook uit dat het begrip in de praktijk uitermate lastig te operationaliseren is. $\mathrm{Bij}$ de besluitvorming kunnen moeilijk te kwantificeren factoren als media-aandacht, onrust blijkend uit activiteiten op sociale media (Facebook, Twitter, Instagram), de hoeveelheid omstanders, de locatie van de voor het publiek toegankelijke plaats en/of de functie van de persoon van het slachtoffer allemaal een rol spelen, maar de waardering van deze factoren verschilt onder de respondenten. Een aantal respondenten vat de 'maatschappelijke onrust' op als een soort light-variant van de 'geschokte rechtsorde', wat het gevaar met zich brengt dat (net als bij de 12-jaarsgrond voor voorlopige hechtenis) de feitelijke onderbouwing ervan niet aan de Straatsburgse maat is: het risico is immers dat de feiten als zodanig vereenzelvigd worden met maatschappelijke onrust. Recente uitspraken van het EHRM tegen Nederland ${ }^{30}$ bevestigen op dit punt wat we sinds arresten als Buzadji $t$. Moldavië ${ }^{31}$ en Geisterfer $t$. Nederland ${ }^{32}$ eigenlijk al wisten: een op de 12-jaarsgrond (en dus public disorder) gegronde voorlopige hechtenis, hoe kortdurend ook, is alleen gerechtvaardigd als concreet wordt onderbouwd dat de invrijheidstelling van de verdachte tot daadwerkelijke public disorder zal leiden. De anticipatie op een vrijheidsstraf is in ieder geval niet te beschouwen als een rechtvaardiging voor (voortduring van)

28. Kamerstukken II 2011/12, 33 360, nr. 4, p. 6, zie ook Kamerstukken II 2011/12, 33 360, nr. 3, p. 4-5 en p. 15.

29. Lindeman e.a. 2020, p. 76-77.

30. EHRM 9 februari 2021, nr. 73329/16 (Hasselbaink t. Nederland), EHRM 9 februari 2021, nr. 69491/16 (Zohlandt t. Nederland) en EHRM 9 februari 2021, nr. 10982/15 (Maassen t. Nederland), EHRC Updates 2021, 61, 63 en 71, m.nt. J.H. Crijns \& Y.M. v/d Brink.

31. EHRM (GC) 5 juli 2016, nr. 23755/07, EHRC 2017/30 m.nt. Crijns (Buzadji t. Moldavië).

32. EHRM 9 december 2014, nr. 15911/08, EHRC 2015/57 m.nt. v/d Brink (Geisterfer $t$. Nederland). voorlopige hechtenis vanwege public disorder. ${ }^{33}$ Het onderbouwen van public disorder met een algemene, abstracte aanname (bijvoorbeeld: elke klap aan een politieagent veroorzaakt maatschappelijke onrust) is dus niet voldoende. In vergelijkbare zin zal ook een al te algemene onderbouwing van het recidivegevaar de toets van het EHRM niet doorstaan. De doorgaans extensieve interpretatie van die (juist in het kader van het snelrecht) veelgebruikte grond voor voorlopige hechtenis staat dus ook op gespannen voet met artikel 5 EVRM. De recente arresten laten al met al nog eens nadrukkelijk zien dat het EHRM geen ruimte ziet voor generieke toepassing van voorlopige hechtenis, waarmee het moeizame karakter van de lik-op-stukgedachte in het algemeen en de nieuwe snelrechtgrond in het bijzonder nogmaals is onderstreept. Maatwerk moet het adagium zijn. ${ }^{34}$

In het evaluatieonderzoek hebben wij ook informatie opgehaald over het snelrecht in de praktijk. ${ }^{35}$ Zoals ook al uit eerder onderzoek was gebleken, wordt supersnelrecht eigenlijk alleen in de drie grote steden structureel toegepast. ${ }^{36}$ Onze indruk was dat in die steden het snelrecht niet of op beperkte schaal werd ingezet. In een aantal andere arrondissementen werd snelrecht wel gebruikt, maar (dus) doorgaans niet voor de in de snelrechtgrond genoemde feiten. Er zijn ook arrondissementen waar (super)snelrecht niet of alleen sporadisch wordt gebruikt (bijvoorbeeld in het kader van oud en nieuw). Het beeld dat wij uit het onderzoek kregen, is dat voor een succesvolle praktijk van (super)snelrecht een bestendig aanbod van zaken nodig is dat getalsmatig rechtvaardigt dat de zittingsruimte gereserveerd wordt. Het aanbod van (super)snelrechtwaardige zaken bleek uiteindelijk nogal schraal: winkeldiefstallen en vergelijkbare op heterdaad ontdekte misdrijven, gepleegd door recidivisten. Kortom, de zaken waarvan iedereen eigenlijk zeker weet hoe ze zullen eindigen en waarin ook de verdachten belang kunnen hebben bij snelle afdoening. ${ }^{37}$ De volgende stap - het beschikbaar maken van (meer) snelrechtcapaciteit voor de ietwat uitdagender zaken, waarvoor in de twee weken tot de zitting ook écht nog aanvullend onderzoek gedaan moet worden - bleek voor veel arrondissementen een behoorlijke horde. ${ }^{38}$ Daartoe zal in ieder geval de logistiek van de belangrijkste ketenpartners ook moeten zijn afgestemd op het snelrecht. Een slachtoffer moet zich bijvoorbeeld wel als benadeelde partij kunnen voegen. Juist als het om lichamelijk letsel gaat, zoals nogal eens het geval is bij geweld tegen personen met een publieke taak, is het maar de vraag of dat zo snel kan. Bovendien moet de verdediging ook

33. EHRM 9 februari 2021, nr. 10982/15 (Maassen t. Nederland), § 62

34. Y. Buruma, 'Voorlopige hechtenis: een buikpijndossier', NJB 2021, 905, p. 965.

35. Lindeman e.a. 2020, p. 92-94.

36. M. van Weerden, A. Benschop, N. Liebregts, T. Blom \& D.J. Korf, Evaluatie Supersnelrecht, Amsterdam: Rozenberg Publishers 2016.

37. Zie de voorbeelden in J.W. Soeteman, 'Raadsman ter terechtzitting' in: P.T.C. van Kampen en N. van der Laan (red.), Handboek Verdediging, Deventer: Kluwer 2021, p. 419-508, p. 492.

38. Lindeman e.a. 2020, p. 94, p. 101. 
'mee' willen. Het weigeren afstand te doen van de dagvaardingstermijn kan de supersnelrechtzitting frustreren, terwijl een snelrechtzitting vrij eenvoudig kan stranden als niet te negeren onderzoekswensen worden geformuleerd: de post Keskin-jurisprudentie van de HR zou juist in gevallen van (uitgaans)geweld (al dan niet tegen personen met een publieke functie) of coronaspugers (zie ook 3.3 hierna) consequenties kunnen hebben voor de snelrechtpraktijk, omdat zij kan leiden tot meer situaties waarin getuigen op zitting (of door de RC) moeten worden gehoord. ${ }^{39}$ Dit past natuurlijk niet goed in de organisatie van (super)snelrecht.

Deze uitdagingen betekenen niet dat er weerstand is tegen (super)snelrecht, integendeel zelfs. In de in het onderzoek betrokken arrondissementen waar dat nog niet het geval was, spraken rechters en officieren van justitie de wens uit dat supersnelrecht structureel zou kunnen worden ingezet voor de rechttoe-rechtaanzaken. ${ }^{40}$ Ook zien verschillende respondenten duidelijke meerwaarde in snelrecht voor niet-gedetineerden: een iets minder strak keurslijf dat nog steeds tot de begeerde snelle berechting zou kunnen leiden. Want dat is een opvatting die breed wordt gedeeld, ook wel door advocaten: snelle berechting is echt het beste. Die snelle berechting hoeft, ook volgens officieren van justitie en rechters, echter niet per se gepaard te gaan met een onvoorwaardelijke vrijheidsstraf. Ook een wat ruimere termijn dan twee weken wordt niet als een probleem gezien. Maatwerk wordt als het sleutelbegrip naar voren gebracht. Het (super)snelrecht werd door respondenten zeker niet alleen als een lik-op-stukinstrument gezien, maar veeleer als een efficiënte werkwijze, waarbij 'efficient' ook betrokken werd op de inhoud van de berechting: de verdachte weet nog precies waar het over gaat en voelt dus ook direct waarvoor hij wordt gestraft. Een dergelijk effect is volgens respondenten echter ook met een strafbeschikking (en dus een taakstraf) te bereiken. ${ }^{41}$ Heel kort samengevat komt onze evaluatie er dus op neer dat de snelrechtgrond voor voorlopige hechtenis amper toegevoegde waarde heeft en dat (ook los van de snelrechtgrond) de verwachtingen van het (super)snelrecht als instrument in het kader van de lik-op-stukaanpak niet te hooggespannen moeten zijn: de voorlopige hechtenis-'mal' waar de zaken doorheen moeten (m.n. grond en anticipatiegebod en termijn van zeventien dagen) lijkt eigenlijk veel beter op andersoortige zaken te passen: de zogenoemde veelvoorkomende criminaliteit (VVC), vaak gepleegd door recidivisten. Maar dat

39. Zie bijvoorbeeld HR 11 mei 2021, ECLI:NL:HR:2021:693, met betrekking tot een eenvoudige belediging (spugen in het gezicht van een klant door een taxichauffeur). De HR casseerde omdat niet zonder meer duidelijk was waarom het niet kunnen ondervragen van de enige twee belastende ooggetuigen niet in strijd was met art. 6 EVRM. De stelling dat de twee bij de politie afgelegde verklaringen slechts steunbewijs waren bij de foto van het bespuugde gezicht, kon de HR niet overtuigen omdat de 'voor [het] bewijs gebruikte verklaringen van getuigen zich niet beperken tot waarneming van spuug op voorhoofd en bril van aangever maar tevens betrekking hebben op gedragingen van verdachte'.

40. Lindeman e.a. 2020 , p. 82

41. Lindeman e.a. 2020, p. 102. zijn eigenlijk niet echt de zaken die we associëren met maatschappelijke onrust en lik-op-stuk. En zelfs in die zaken hebben de verdachten geregeld een zodanig complexe persoonlijkheid, dat snelrecht niet altijd mogelijk is. Andere gevallen waarin de behoefte aan lik-op-stuk bestaat, kunnen volgens onze respondenten ook goed worden afgedaan zonder toepassing van voorlopige hechtenis, bijvoorbeeld door snelrecht voor niet-gedetineerden of door buitengerechtelijke afdoening.

De crux blijft toch dat de lik-op-stukzaken moeilijk zijn te definiëren en dat het vaak de (politieke) waan van de dag is die bepaalt waar lik-op-stuk nodig is. Slechts een enkele generieke categorie van zaken (bijvoorbeeld misdragingen tegen personen met een publieke taak tijdens evenementen, zoals oud en nieuw) lijkt daarbij nog relatief vaak te passen in de snelrechtmal, maar ook in die zaken ligt het risico op de loer dat berechting binnen zeventien dagen niet lukt. Een structuur waarin die zaken vervolgens nog steeds wel binnen een vaste termijn (bijvoorbeeld drie maanden) worden behandeld, zou daar een mooi vangnet zijn.

\subsection{Coronaspugers en avondklokrellen:} prototype snelrecht?

Tijdens ons onderzoek brak de coronacrisis uit, en ineens kwam daar het schijnbaar 'ideale' snelrechtgrondfeit voorbij: het coronaspugen. Hier was sprake van gedrag dat inderdaad naar vrijwel ieders mening zonder meer tot maatschappelijke onrust leidt, dat vaak gemakkelijk te bewijzen is en waarvoor, zo bleek al snel, rechters (doorgaans strenger dan in vergelijkbare zaken van voor de crisis) onvoorwaardelijke vrijheidsstraffen oplegden. ${ }^{42}$ In ons onderzoek konden we de casus voorleggen aan respondenten. Al snel bleek echter dat ook hier voor het gebruik van de snelrechtgrond niet per se veel plaats was: de zaken waren doorgaans zó eenvoudig dat supersnelrecht ook van toepassing kon zijn. En de personen die zich aan dit gedrag schuldig maakten, bleken toch vaak geen onbekenden van de politie, waardoor andermaal de recidivegrond uitkomst kon bieden.

De avondklokrellen boden (nadat wij ons onderzoek al hadden afgerond) in dit opzicht ook nieuwe casuistiek. Uiteraard werd door de 'keihard aanpakken'-fracties in de Tweede Kamer moord en brand geschreeuwd: het 'tuig' moest zo snel mogelijk aan de hoogste boom opgeknoopt:

'We zien tuig dat onze agenten aanvalt (...). Op het moment dat die gasten gepakt zijn, wil ik dat ze snel voor een rechter komen te staan. Ik zou graag van het kabinet willen weten hoe vaak er de afgelopen dagen supersnelrecht is ingezet en, als dat niet is ingezet, waarom niet. (...) In ons land staan zware straffen op zaken als opruiing of openlijke geweldpleging. Dan kun je voor jaren de bak in. Ik zou willen dat dat het geval is. ${ }^{43}$

42. Lindeman e.a. 2020 , p. 98-100.

43. Handelingen // 2020/21, nr. 49, item 4, p. 8. Aan het woord is Kamerlid Yeşilgöz-Zegerius van de VVD, die over het hoofd ziet dat de super- 
In hetzelfde debat vertelt de minister van Justitie en Veiligheid dat het $\mathrm{OM}$ een aangepaste richtlijn heeft opgesteld, ${ }^{44}$ die voor zover wij weten alleen voor intern gebruik bedoeld was. De rechtspraak toonde zich (opnieuw) van haar harde kant: er werden onvoorwaardelijke vrijheidsstraffen opgelegd in situaties waarvoor normaal gesproken met taakstraffen werd volstaan. Sommige zaken stonden op supersnelrecht, andere op snelrecht en weer andere werden pas later afgedaan. De media-aandacht was navenant, niet in de laatste plaats omdat de rellen min of meer samenvielen met de behandeling van de hieronder nog te bespreken uitbreiding van het taakstrafverbod in de Tweede Kamer: voor- en tegenstanders kregen aan vrijwel alle talkshowtafels de gelegenheid zich erover uit te laten.

Hoewel nog betrekkelijk kort geleden, lijkt het toch gerechtvaardigd om te zeggen dat OM en Rechtspraak zich misschien wel wat al te zeer hebben laten meeslepen door de toon van het politieke debat en de crisissituatie. In een aantal gevallen werden de scherpe kantjes in hoger beroep er alweer afgehaald. ${ }^{45}$ Toen in april nog wat rellen op de zitting stonden in Rotterdam, werd door een aanwezige journalist onder meer het volgende opgetekend: ${ }^{46}$

'Volgens officier van justitie Ad de Beer zijn er 25 tot 30 relschoppers in het vizier en zijn de meesten zoals deze verdachte. "Gewoon jongens die bezig zijn met hun toekomst, met een opleiding of een baan. Niet de usual suspects die bewust komen rellen."

De officier wijst er ook op dat het lastig is om verdachten te herkennen. "Het is donker, ze dragen een mondkapje en een hoodie. Er zijn altijd mensen die dat vergeten. We pakken vooral de sukkels."

Ad de Beer makte ook duidelijk dat er nu, zeven weken na de rellen, lagere straffen worden geëist dan bij de eerste lichting. "Het instrument van het strafrecht om de orde te handhaven in de samenleving mag wel weer een beetje terug in zijn hok. Dat hebben we met elkaar besloten omdat alle rellen voorlopig achter de rug zijn.'

\subsection{Het taakstrafverbod als aanjager van} snelrecht en voorlopige hechtenis?

In de zomer van 2020 zag het wetsvoorstel ter uitbreiding van het taakstrafverbod bij geweld tegen personen met een publieke taak het licht. ${ }^{47}$ In dit wetsvoorstel

snelrechter (een politierechter) geen gevangenisstraf van meer dan een jaar mag opleggen.

44. Handelingen I/ 2020/21, nr. 49, item 4, p. 9.

45. Bijvorbeeld in de zaak 'Ayoub', die zo'n beetje model stond voor de situatie. Hij werd door de supersnelrechter tot twee maanden cel veroordeeld, maar in appel na 22 dagen zitten vrijgelaten, www.ad.nl/denhaag/stenengooiende-relschopper-ayoub-19-weer-vrij-start-dezeweek-nog-met-opleiding a67ccf48/.

46. www.rijnmond.nl/nieuws/204817/Rotterdammers-krijgen-cel-entaakstraf-voor-rellen-avondklok.

47. Kamerstukken II 2019/20, 35 528, nrs. 1-3; Lindeman e.a. 2020, p. 39-42. Zie ook R.A. Hoving, 'Het wetsvoorstel uitbreiding taakstrafverbod. Een olifant in de porseleinkast van de straftoemeting', NJB 2020, p. 308-313. werd voorgesteld het taakstrafverbod van artikel $22 \mathrm{~b} \mathrm{Sr}$ uit te breiden zodat het ook van toepassing is op

'een van de misdrijven omschreven in de artikelen 300 tot en met 303, indien het misdrijf is begaan tegen een ambtenaar van politie, een medewerker van brandweer of ambulance of een buitengewoon opsporingsambtenaar in de uitoefening van zijn publieke taak in het kader van de handhaving van de orde of veiligheid of tegen een andere persoon die in dat kader een publieke taak uitoefent.' ${ }^{48}$

Een belangrijk verband tussen dit voorstel en de in 3.2 besproken WUGVH is dat het uitgebreide taakstrafverbod een significant gat kan dichten tussen de hiervoor genoemde lik-op-stukambities (o.m. neergelegd in de ELA) en de praktijk. Waar nu door het OM en de rechter vaak nog aan taakstraffen wordt gedacht, zal na een uitbreiding van het taakstrafverbod een onvoorwaardelijke gevangenisstraf eerder in beeld kunnen/moeten komen, waardoor het anticipatiegebod minder snel in de weg zal staan aan voorlopige hechtenis (en dus aan snelrecht). ${ }^{49}$

Ook in deze wetgevingsoperatie betoonden veel van de gebruikelijke consultatiepartners (NOvA, RvdR, NVvR, Reclassering) zich geen voorstander van het voorstel en ook de Afdeling advisering van de Raad van State was uitermate zuinig. ${ }^{50}$

Het consultatieadvies van het OM beperkte zich tot 'geen commentaar', wat gezien veel van de relevante strafvorderingsrichtlijnen verbaast: die richtlijnen wijzen namelijk in veel van de door het wetsvoorstel bestreken gevallen (ook) in de richting van een taakstraf. In de Aanwijzing kader voor strafvordering meerderjarigen (Stcrt. 2019, 14890) wordt over geweld tegen personen met een publieke taak zelfs gezegd [onze cursivering $\mathcal{f} L, L v L$ G $B v d V]$ :

'Het OM kiest juist hier voor effectieve en betekenisvolle interventies. Interventies die de dader confronteren met de gevolgen van zijn daad en bijdragen aan gedragsverandering. Denk hierbij aan (eventueel combinaties van) gerichte merkstraffen, leerstraffen als bijzonder voormaarde, gedragsaanmijzingen en het maken van excuses aan het slachtoffer. Het uitgangspunt van de sanctie in de richtlijn wordt met 200\% verhoogd als signaal dat dit soort crimineel gedrag niet wordt getolereerd.'

Kortom: het wetsvoorstel sluit slecht aan op het beleid van het OM. Ook tijdens ons onderzoek gaven respondenten van OM-zijde aan dat zij er weinig heil in zagen. ${ }^{51}$ De behandeling van het wetsvoorstel in de Tweede Kamer riep onderwijl een déjà-vu met het debat

48. Kamerstukken II 2019/20, 35 528, nrs. 1-3; Lindeman e.a. 2020, p. 39-42. Zie ook R.A. Hoving, 'Het wetsvoorstel uitbreiding taakstrafverbod. Een olifant in de porseleinkast van de straftoemeting', NJB 2020, p. 308-313.

49. Lindeman e.a. 2020, p. 41, p. 42, met name p. 122.

50. Kamerstukken I/ 2019/20, 35 528, nr. 4.

51. Lindeman e.a. 2020, p. 103. 
over de snelrechtgrond op: de veronderstelling dat de maatschappij altijd beter af is met onvoorwaardelijke vrijheidsstraffen werd niet concreet onderbouwd, ${ }^{52}$ en toch besloot een meerderheid van de Tweede Kamer dat de rechterlijke straftoemetingsvrijheid ervoor moet wijken. Wél onderbouwde argumenten, bijvoorbeeld dat taakgestraften minder recidiveren en dat de detentieschade die door rauwelijkse opsluiting kan worden veroorzaakt voor de maatschappij wel eens nadeliger kan zijn dan de gevoelens van onrust en verontwaardiging, werden door een meerderheid van de Tweede Kamer niet gehoord. ${ }^{53}$ Hier speelde waarschijnlijk ook een rol dat de behandeling in de Tweede Kamer min of meer samenviel met de eerste avondklokrellen: geen ideale situatie om de nuance te willen zien (zoals hiervoor in par. 3.3 al bleek). De behandeling viel ook samen met de val van het kabinet-Rutte III. In dezelfde week dat dit kabinet voor het eerst reageerde op het vernietigende rapport Ongekend Onrecht van de Commissie-Van Dam (strekking, o.a.: door een gebrek aan discretionaire ruimte voor de rechter werden burgers door de overheid vermalen), bestond dezelfde Van Dam het om in de Tweede Kamer het inperken van de rechterlijke vrijheid te verdedigen:

'Het moet gewoon helder zijn (...) dat het gewoon brommen is als je met je handen aan hulpverleners, politiemensen en brandweermensen komt en hun feitelijk en fysiek letsel toebrengt. De taakstraf, die van origine een alternatief was, staat dan inderdaad in de orde een tandje lager.' 54

In ons rapport over de WUGVH hebben wij de vrees uitgesproken dat de uitbreiding van het taakstrafverbod kan bijdragen aan een toename van het aantal gevallen waarin de snelrechtgrond voor voorlopige hechtenis zou kunnen worden toegepast. Daar staat tegenover dat de andere bezwaren tegen toepassing van snelrecht (zaken te ingewikkeld, abstracte i.p.v. concrete onderbouwing van $\mathrm{VH}$-gronden) natuurlijk blijven bestaan. Bovendien is in de praktijk al gebleken (en door de Hoge Raad gesauveerd) dat het taakstrafverbod omzeild wordt door een gevangenisstraf van één dag op te leggen in combinatie met een taakstraf. ${ }^{55}$

Wij hebben deze relativeringen in ons rapport ook benoemd ${ }^{56}$ en gesteld dat wij met enige zorg constateren 'dat het voorstel voor de Wet uitbreiding taakstrafver-

52. Handelingen // 2020/21, nr. 48, item 25. Zie bijvoorbeeld de gedachtewisseling tussen Van den Berge (GL) en Van Dam (CDA) op p. 17-18.

53. Zie bijvoorbeeld het consultatieadvies van Reclassering Nederland (namens 3RO), bijlage (blg-940485) bij Kamerstukken // 2019/20, 35 528 , nr. 3. Voor een veel uitgebreidere bespreking van al deze argumenten verwijzen wij naar J.D. Schmahl \& L.W. Verbeek, ‘Uitbreiding taakstrafverbod: een schoolvoorbeeld van onomkeerbare symboolpolitiek', DD 2021/43

54. Handelingen // 2020/21, nr. 48, item 25, p. 16. Zie ook https:// twitter.com/ChrisvanDamCDA/status/1354425159994761216.

55. 20 februari 2018, ECLI:NL:HR:2018:202, NJ 2018/219 m.nt. T. Kooijmans (Valkenburgse zedenzaak), zie ook L. Noyon, 'De geschiedenis van het "taakstrafverbod" van artikel 22b Sr: een klucht vol verwarring', AA 2017, p. 307-315, met name par. 3.

56. Lindeman e.a. 2020, p. 41, p. 42, met name p. 122 bod de problematiek nogal eenzijdig benadert en dat er geen duidelijke voeling en koppeling lijkt te zijn met de praktijk, het beleid en de in het onderhavige rapport genoemde ontwikkelingen. Te vrezen is een herhaling van het proces van de totstandkoming van de WUGVH: ingevoerd na een wetgevingsproces dat bol stond van bezwaren, vraagtekens en twijfels, en zeer beperkt toegepast vanwege diezelfde bezwaren en twijfels.'

Dat minister voor Rechtsbescherming Dekker ons evaluatierapport met zijn beleidsreactie pas ná de stemming over de uitbreiding van het taakstrafverbod aan de Tweede Kamer heeft opgestuurd (in februari 2021; ons rapport is in juli 2020 opgeleverd), ${ }^{57}$ willen wij de lezer in dit verband niet onthouden.

Ten tijde van het schrijven van dit artikel had het zogenoemde voorbereidend onderzoek in de Eerste Kamer plaatsgehad en werd op de website van de Eerste Kamer aangekondigd dat er op 8 juni 2021 een deskundigenbijeenkomst zal worden georganiseerd. ${ }^{58}$ Hopelijk zal hetgeen daar op tafel komt bijdragen aan het besef dat met deze wet niets gewonnen gaat worden.

\subsection{Achterstanden wegwerken met snelrecht?}

De coronacrisis heeft achterstanden veroorzaakt in de strafrechtketen. ${ }^{59}$ De oplossing voor het wegwerken van die achterstanden wordt mede gezocht in het snelrecht. ${ }^{60}$ Een andere belangrijke oplossingsrichting is het uitbreiden van de mogelijkheden van buitengerechtelijke afdoening. Waar het in het voorgaande vooral ging om het snelrecht als 'optimum remedium' tegen bepaalde strafbare feiten die maatschappelijke onrust zouden veroorzaken en die gericht zijn tegen personen met een publieke taak, wordt nu ook gekeken naar het snelrecht als doelmatigheidsinstrument. In dat kader heeft het Bestuurlijk Ketenberaad (BKB, zie par. 1 hiervoor) in een actieplan en een position paper aanbevelingen gedaan die, voor zover wij kunnen beoordelen, zijn omarmd door het $\mathrm{OM}$ en de Rechtspraak. Daarin wordt, zoals al vermeld, ook nadrukkelijk de mogelijkheid van snelrecht voor niet-gedetineerden genoemd. Het snelrecht wordt gezien als een instrument om doorlooptijden te bekorten, maar er wordt wel voor gewaarschuwd dat snelrecht niet altijd en niet gemakkelijk kan worden ingezet. In het actieplan wordt bijvoorbeeld nadrukkelijk onderkend dat achter de ambitie van versnelde afdoening een 'complexe, weerbarstige werkelijkheid' schuilgaat. De zittingscapaciteit, het aanbod van de zaken, de logistiek en de capaciteit van de ketenpartners (naast politie, OM en Rechtspraak noemt het BKB Reclassering, slachtofferhulp, NIFP, NFI etc.), moeten

57. Kamerstukken I/ 2020/21, 29 279, nr. 638.

58. www.eerstekamer.nl/wetsvoorstel/35528_wet_uitbreiding.

59. Overigens kan vrij veilig gesteld worden dat die achterstanden er ook zonder crisis wel waren geweest. Dit is echter niet de plaats daarop nader te reflecteren. Zie bijvoorbeeld dit bericht van vóór de crisis: nos.nl/artikel/2326024-rechtspraak-loopt-vast-meer-dan-20-000strafzaken-uitgesteld.

60. 'Actieplan strafrechtketen', Bestuurlijk Ketenberaad, 6 november 2020, bijlage (blg-956897) bij Kamerstukken I/ 2020/21, 29 279, nr. 628, p. 6. 
goed op elkaar aansluiten. En '[u]iteraard moet ook de advocatuur in dit proces betrokken worden'. ${ }^{61}$

Alle beleidsjargon ten spijt, is ook in het actieplan weinig te lezen over de parameters waarbinnen een snelrechtprocedure zou passen. Weliswaar wordt onderkend dat het alleen werkt als alle betrokkenen het willen, maar wat er nu gaat veranderen om dat voor elkaar te krijgen blijft wat vaag. Bovendien valt op dat de advocatuur andermaal niet als volwaardige ketenpartner wordt gezien, waar bijvoorbeeld SHN dat wel is. Van der Meij en Bektesevic hebben zich eerder dit jaar in dit tijdschrift al kritisch betoond over de 'blinde vlek' die beleidsmakers in dit opzicht hebben en over de nog steeds gebrekkige financiering van de rechtsbijstand. ${ }^{62}$ Het belang van het faciliteren van adequate rechtsbijstand is intussen moeilijk te overschatten, zeker als de verdachte in voorlopige hechtenis zit. Juist dan wordt de verdediging immers met belemmeringen geconfronteerd ten aanzien van het voorbereiden van de strafzaak. De huizen van bewaring zijn allang niet meer ingericht op het faciliteren van de verdediging - een taak die zij eigenlijk wel hebben. Advocaten hebben bijvoorbeeld soms moeite om hun cliënten tijdig te spreken te krijgen en de verdachte kan niet altijd alle processtukken bestuderen. ${ }^{63}$ Bij het landelijk en meer uniform inrichten van snelrechtprocedures moet hieraan - het beginsel van minimale beperkingen ${ }^{64}$ indachtig - onzes inziens nadrukkelijk aandacht worden besteed.

Er zal dus nog veel moeten veranderen, wat bijvoorbeeld ook blijkt uit het jaarplan van de Rechtspraak voor 2021, waarin wordt aangegeven dat (vooral lokaal) nog veel werk te verzetten valt om bij alle gerechten (super)snelrecht in te voeren. ${ }^{65}$ Impliciet volgt hieruit wat we al wisten: het (super)snelrecht is in Nederland nog lang niet zo'n algemeen ingezette modaliteit als we misschien dachten.

\section{Snelrecht 'as we know it' is geen panacee, snelle berechting verdient meer aandacht en regulering}

Laten wij vooropstellen dat niemand iets kan hebben tegen snelle, efficiënte en pragmatische strafrechtsple-

61. 'Actieplan strafrechtketen', Bestuurlijk Ketenberaad, 6 november 2020, bijlage (blg-956897) bij Kamerstukken // 2020/21, 29 279, nr. 628, p. 6.

62. P.P.J. van der Meij en D. Bektesevic, 'Herwaardering van de strafrechtadvocaat', Boom Strafblad 2021 (1), p. 10-17

63. P. Jacobs en J.M.W. Lindeman, 'De tenuitvoerlegging van de voorlopige hechtenis. Belemmerend voor of juist in dienst van de voorbereiding van de strafzaak?', Strafblad 2019 (2), p. 6-14.

64. Art. 2 lid 4 PBW, een bepaling die haar oorsprong vindt in art. 26bis van de oude Beginselenwet gevangeniswezen, waarin was geregeld dat 'onveroordeelden' aan geen andere beperkingen mochten worden onderworpen 'dan die voor het doel hunner opsluiting of in het belang der orde volstrekt noodzakelijk zijn', zie Jacobs \& Lindeman 2019, p. 8.

65. Jaarplan Rechtspraak 2021, p. 22. ging. De officieren van justitie, advocaten en rechters die wij hebben gesproken, stonden dan ook in meerderheid positief tegenover de toepassing van snelrecht als zodanig. In zaken die zich daarvoor lenen is snelle berechting altijd een goed idee. Het categorisch van toepassing verklaren van de snelrechtprocedure op bepaalde delictsgroepen past daar echter niet bij. Het 'keurslijf' van de voorlopige hechtenis als voorwaarde voor snelrecht is te knellend voor een grote groep strafzaken die in potentie prima geschikt zou zijn voor snelle berechting. Hierdoor sneuvelen ambities en blijft de buitenstaander achter met het beeld dat de zo vurig beleden beloften van de politiek stranden in de traag draaiende molens van de strafrechtketen.

De WUGVH is een voorbeeld van zo'n belofte. Van meet af aan is de snelrechtgrond als symboolpolitiek beschouwd en in de MvT bij het wetsvoorstel gaf de minister eigenlijk ook gewoon toe dat de wens de vader van de gedachte was: hij kon niet hardmaken dat snelrecht inderdaad effectiever is, maar stelt dat 'vooral de wens om snel op te treden in bepaalde gevallen waarin maatschappelijke onrust is ontstaan, ten grondslag ligt aan het wetsvoorstel.' 66

In de afgelopen kabinetsperiodes zijn in vergelijkende zin verschillende wetsvoorstellen aangenomen waarvan vrijwel iedereen uit de praktijk vond dat ze er niet moesten komen. ${ }^{67}$ Onze evaluatie van een van deze wetgevingsoperaties wijst uit dat deze waarschuwingen terecht zijn geweest, en dat de praktijk is opgezadeld met symboolwetgeving gebaseerd op aannames die niet juist zijn. Wij zien het met lede ogen gebeuren dat deze situatie zich opnieuw dreigt voor te doen bij de uitbreiding van het taakstrafverbod.

De realiteit omtrent het snelrecht is onderwijl dat er slechts op een beperkt aantal plaatsen een goed geoliede machine is, die vooral draait op zogenoemde VVCzaken. ${ }^{68}$ Dit strookt helemaal niet met de politieke wensen met betrekking tot snelrecht in zogenoemde HICzaken: ${ }^{69}$ juist in die zaken is vaak, zowel in het belang van het slachtoffer als in het belang van de verdachte als in het belang van de waarheidsvinding, maatwerk vereist, hetgeen niet in de snelrechtmal past. Niet alleen lopen (politieke) verwachtingen en de praktijk van de rechtspleging dus uiteen, ook blijkt het snelrecht - door zijn ongereguleerde aard - vatbaar voor sterk politiek gemotiveerde toepassing die, zeker in crisistijd, rechterlijke uitspraken direct kan beïnvloeden. De rechtspraak rond coronaspugers en de avondklokrellen is daarvan een voorbeeld. De hiervoor in paragraaf 3.3 aangehaalde uitspraken van een Rotterdamse officier van justitie laten zien dat het moment van berechting kennelijk van invloed is op de strafmaat: als een gelijkwaardig (op hetzelfde moment gepleegd) feit een paar maanden later op

66. Kamerstukken // 2011/12, 33 360, nr. 3, p. 13.

67. Recente voorbeelden zijn de Wet straffen en beschermen (Stb. 2020, 224) en de Wet handhaving kraakverbod (Kamerstukken I/ 2019/20, 35 296, nr. 1-3, inmiddels in de Eerste Kamer aangenomen: Handelingen / 2020/21, nr. 32, item 9, p. 1).

68. Veelvoorkomende Criminaliteit.

69. High Impact Crime. 
zitting staat, maakt het al uit. Het lijkt ons een belangrijk argument tegen een té snelle berechting. Het is van belang dat de inzet van het snelrecht niet - al dan niet door politieke druk - tevens een multipliereffect met zich brengt.

Dat intussen het BKB van de Strafrechtketen (alleen de naam al...) het snelrecht ziet als een efficiency-instrument stemt - zeker in het licht van het voorgaande niet helemaal gerust. Enerzijds is er kennelijk (eindelijk) een beweging om in het hele land de machines op te tuigen. Anderzijds moet ervoor worden gewaakt dat het middel tot doel wordt verheven, terwijl nog altijd geen waarborgen voor een op de individuele zaak toegesneden toepassing zijn geïntroduceerd.

Het voorgaande maakt, al met al, duidelijk dat het snelrecht bepaald geen panacee is en dat vermoedelijk ook nooit zal worden. Het komt ons voor dat het dogma overboord moet dat alleen met direct opsluiten van de verdachte de mogelijke maatschappelijke onrust kan worden gedempt. De (bredere) introductie van snelrecht voor niet-gedetineerden is dus een goede ontwikkeling. Als de maatschappij en de slachtoffers de garantie krijgen dat er binnen een bepaalde termijn (zeg maximaal drie maanden) een vonnis ligt en dat onvoorwaardelijke vrijheidsstraffen vervolgens ook weer binnen een zeer afzienbare termijn ten uitvoer zullen worden gelegd, zou dat in de meeste gevallen voldoende zijn. We benadrukken nog maar eens: onderzoek waaruit blijkt dat er een maatschappelijk belang is bij nóg snellere rechtspraak is ons niet bekend. Daarnaast is het breed bekend dat het toepassen van taakstraffen een betekenisvollere manier van straffen is, terwijl juist kortdurende gevangenisstraffen verhoudingsgewijs veel detentieschade aanrichten (zie par. 3.4 hierboven).

Wij hebben in het voorgaande vooral veel zogenoemde incompatibiliteiten genoemd en zouden op basis daarvan willen bepleiten de parameters niet te strak te trekken, om te voorkomen dat toch weer te veel strafzaken níet in de mal passen. Kortom: baseer het beleid op een realistisch en pragmatisch beeld omtrent de strafrechtspleging in het algemeen en de werking van 'lik-op-stuk' in het bijzonder.

Daarbij komt het ons voor dat een aantal procedurele aspecten (zoals termijnen, verdedigingsrechten, positie slachtoffers) nader gereguleerd zou moeten worden (al was het maar in beleidsregels of het strafprocesreglement), zodat alle betrokken partijen begrijpen wat hun te wachten te staat en welke spanningsvelden aan de orde zijn als ze met een snelrechtprocedure te maken krijgen. Een systeem waarin snelle berechting vooropstaat, moet ook zijn voorzien van faciliterende randvoorwaarden en procedurele waarborgen met betrekking tot de rechtsbescherming. Met het werken aan een nieuwe structuur en het doordenken en reguleren van procedurele aspecten en in het geding zijnde rechten wordt ook de politiek meer op afstand gehouden. En dat lijkt ons een van de belangrijkste opgaven. 